\title{
PENENTUAN LOKASI PENANGKAPAN IKAN KARANG DI PERAIRAN PESISIR TIMUR PULAU KEI BESAR MALUKU TENGGARA
}

\author{
Determination of Coral Reef Fishing Area in Eastern Coastal Waters Kei Besar Island, Southeast \\ Maluku
}

Oleh:

\author{
Exist Saraswati ${ }^{1}$, Fis Purwangka², Wazir Mawardi ${ }^{2}$ \\ ${ }^{1}$ Program Studi Teknologi dan Manajemen Perikanan Tangkap, FPIK-IPB \\ ${ }^{2}$ Departemen Pemanfaatan Sumberdaya Perikanan FPIK-IPB \\ *Korespondensi: existsaraswati98@gmail.com
}

\begin{abstract}
ABSTRAK
Ikan karang merupakan ikan bernilai ekonomis tinggi dan sering dimanfaatkan sebagai target tangkapan oleh nelayan. Keberhasilan pemanfaatan ikan karang agar optimal didukung oleh beberapa faktor, salah satunya daerah penangkapan ikan. Namun kondisi yang terjadi di masyarakat Pulau Kei Besar adalah bahwa mereka belum mengetahui daerah penangkapan ikan yang potensial. Tujuan penelitian ini adalah menghitung kekayaan jenis dan indeks ekologi ikan karang di perairan pesisir timur Pulau Kei Besar, mengidentifikasi kelimpahan ikan karang yang layak tangkap di perairan pesisir timur Pulau Kei Besar, serta menentukan daerah potensial penangkapan ikan karang di perairan pesisir timur Pulau Kei Besar. Penelitian ini berlangsung dari Oktober 2018 hingga Februari 2019 dimana pengambilan data lapangnya mengambil 9 titik lokasi pada tanggal 3-18 November 2018 dengan menerapkan metode Underwater Visual Census. Analisis yang dilakukan adalah menghitung kelimpahan ikan, biomassa, komposisi jenis, indeks ekologi, ukuran layak tangkap dan pembobotan untuk menentukan daerah penangkapan ikan potensial. Hasil penelitian menunjukkan bahwa kelimpahan dan biomassa ikan paling tinggi terdapat di lokasi Fako dengan 4 dari 9 lokasi pengamatan memiliki persentase jenis ikan yang sudah layak tangkap lebih besar daripada yang belum layak tangkap. Lokasi perairan Kilwait, Ohoirenan, Ngufit Bawah, dan Yamtel bukan daerah yang potensial untuk menangkap ikan karang. Perairan Weduar, Hollat, dan Ohoifau merupakan perairan yang cukup potensial untuk menangkap ikan karang serta perairan Ohoiwait dan Fako merupakan perairan yang potensial untuk menangkap ikan karang. Penelitian ini diharapkan dapat bermanfaat dalam memberikan informasi kepada nelayan terkait daerah penangkapan ikan agar kegiatan penangkapan ikan yang dilakukan lebih optimal.
\end{abstract}

Kata Kunci: ikan karang, lokasi penangkapan ikan, pulau Kei Besar, underwater visual census

\begin{abstract}
Coral reef fish are high economic value fish and often utilized as target catches by fishermen. The successful of the reef fish utilization to be optimally supported by several factors, one of them is fishing grounds. But the conditions that occurred in the Kei Besar Island community are that they don't know the potential fishing grounds. The purpose of this study was to calculate the compotitoin of reef fish and index ecology in the Kei Besar Island, to identify reef fish that were suitable for capture in the eastern coastal waters of Kei Besar Island, and to determine the potential areas for coral reef fish in the Kei Besar Island. This research held from October 2018 to February 2019, with field data collections at 9 location on November 3rd-18 th 2018 using underwater visual census method. Data analysis asses fish abundance, biomass, family composition, ecological index, measuring viable catch and determine potential fishing areas. The results showed that the location with highest abundance and biomass is
\end{abstract}


Fako. Kilwait, Ngufit Bawah, Ohoirenan and Yamtel not a potential area to catch coral reef fish. Weduar, Hollat, and Ohoifau is enough potential area to catch coral reef fish. Ohoiwait and Fako are a potential fishing ground to catch coral reef fish. This research expected to be useful in providing information to fishers about fishing ground so that fishing activities are more optimally.

Keywords: coral reef fish, fishing area, Kei Besar island, underwater visual census

\section{PENDAHULUAN}

Pulau Kei Besar yang terletak di Kabupaten Maluku Tenggara memiliki potensi di bidang perikanan yang cukup baik. Potensi ini didukung dengan kelengkapan ekosistem yang dimiliki dan letak yang strategis di antara Laut Banda dan Laut Arafura (Triandiza 2013). Kementerian Kelautan dan Perikanan juga telah memberikan julukan kepada Pulau Kei sebagai "Pulau dengan Potensi Tersembunyi Paling Favorit" pada tahun 2016. Salah satu potensi yang ada tersebut berasal dari ekosistem terumbu karang.

Ekosistem terumbu karang merupakan habitat dari banyak jenis ikan karang, baik untuk mencari makan, memijah, atau sebagai tempat tinggal. Menurut keputusan Direktur Jendral Kelautan, Pesisir, dan Pulau Pulau Kecil Nomor Kep.44/KP3K/2012 tentang Pedoman Teknik Evaluasi Efektivitas Pengelolaan Kawasan Konservasi Perairan, Pesisir, dan Pulau -Pulau Kecil, ikan karang memiliki nilai ekonomis yang cukup tinggi sehingga sering dijadikan target tangkapan oleh nelayan. Ikan-ikan tersebut dijadikan target tangkapan nelayan baik sebagai ikan konsumsi maupun ikan hias bernilai ekonomis tinggi. Pemanfaatan ikan karang sebagai tangkapan nelayan ini tentu menguntungkan apabila dilakukan dengan optimal.

Optimasi suatu penangkapan ikan ditentukan oleh proses operasi penangkapan ikan itu sendiri. Terdapat beberapa faktor keberhasilan operasi penangkapan ikan, salah satunya adalah daerah penangkapan ikan (Simbolon 2009). Daerah penangkapan ikan merupakan suatu daerah perairan yang dijadikan sasaran aktivitas penangkapan ikan yang optimal dengan menggunakan suatu alat tangkap (Mukhtar 2010). Kriteria yang dapat dijadikan sebagai indikator daerah penangkapan ikan antara lain adalah aspek biologi. Namun kondisi saat ini referensi atau literatur yang menggunakan pendekatan biologi ikan dalam memprediksi daerah penangkapan ikan masih sangat minim, padahal aspek tersebut merupakan ilmu dasar bidang perikanan (Simbolon 2011).

Nelayan Pulau Kei Besar masih tergolong nelayan tradisional dengan menerapkan sistem berburu dalam melakukan kegiatan penangkapan ikan. Mereka melakukan aktivitas penangkapan tanpa mengetahui daerah yang potensial dengan sumberdaya yang ada didalamnya. Nelayan Kei Besar hanya melakukannya penangkapan di sekitar perairan tidak jauh dari pantai dan berdasarkan informasi turun temurun (DKP Maluku Tenggara 2010). Padahal menurut Bukhari et.al (2014), informasi terkait daerah penangkapan ikan sangat diperlukan karena dapat membuat waktu penangkapan lebih efisien. Oleh karena itu, penelitian ini bertujuan untuk mengetahui lokasi penangkapan ikan karang di Pulau Kei Besar.

\section{METODE PENELITIAN}

Objek penelitian dalam penelitian ini adalah ikan karang dengan alat yang digunakan pada saat pengambilan data di lapang meliputi perahu bermotor, Global Positioning System (GPS), alat penyelaman (SCUBA set), kertas newtop, pensil, roll meter, tongkat estimasi, dan kamera underwater. Data yang telah diambil di lapang kemudian di input ke Ms. Excel untuk diolah menjadi berbagai informasi. Selain itu, dibutuhkan pula buku identifikasi ikan untuk memastikan jenis ikan yang ditemukan ketika di lapang yaitu buku Coral Reef Fishes of Indonesia (Allen dan Adrim 2003), Reef Fishes of the East Indies. Tropical Reef Research (Allen dan Erdmann 2012), Reef Fish Identification: Tropical Pacific (Allen et al 2003). 
Penelitian ini dilakukan dari bulan Oktober 2018 hingga Februari 2019, sedangkan pengambilan data lapang dilakukan sejak tanggal 3 November 2018 hingga 18 November 2018. Penelitian ini dilaksanakan di perairan pesisir timur Pulau Kei Besar, Kabupaten Maluku Tenggara meliputi 3 kecamatan yaitu Kecamatan Kei Besar Selatan dilakukan di tiga desa yaitu Desa Kilwait, Weduar, dan Ohoirenan. Empat desa di Kecamatan Kei Besar yaitu Desa Ohoiwait, Ngufit Bawah, Yamtel, dan Fako serta di Kecamatan Kei Besar Utara Timur dilakukan pengambilan data di dua desa yakni Desa Hollat dan Desa Ohoifau. Pemilihan lokasi ini berdasarkan penduduk desa tersebut lebih banyak dibandingkan dengan lokasi lainnya sehingga diasumsikan bahwa lebih banyak masyarakat yang memanfaatkan hasil laut di lokasi-lokasi tersebut. Gambar 1 dan Tabel 1 merupakan peta lokasi penelitian dan titik koordinat masing masing lokasi pengamatannya.

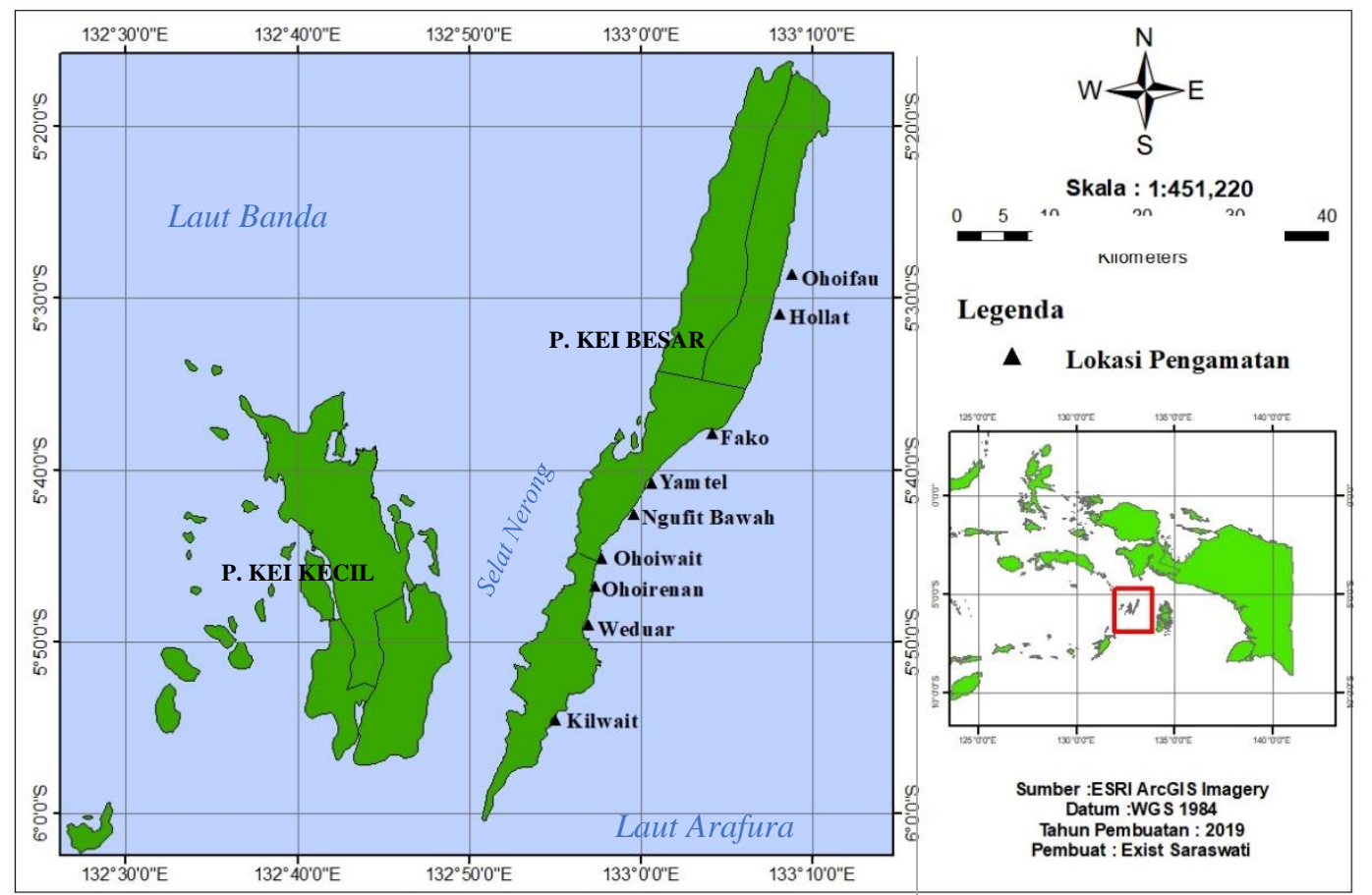

Gambar 1 Lokasi penelitian

Tabel 1 Koordinat lokasi penelitian

\begin{tabular}{llcc}
\hline Kecamatan & \multicolumn{1}{c}{ Lokasi } & Latitude & Longitude \\
\hline Kei Besar Selatan & Kilwait & -5.91115 & 132.91689 \\
& Weduar & -5.81882 & 132.94826 \\
& Ohoirenan & -5.78086 & 132.95493 \\
Kei Besar & Ohoiwait & -5.75388 & 132.96136 \\
& Ngufit Bawah & -5.71104 & 132.99219 \\
& Yamtel & -5.68119 & 133.00992 \\
Kei Besar Utara Timur & Fako & -5.63269 & 133.06900 \\
& Hollat & -5.51643 & 133.13465 \\
& Ohoifau & -5.47731 & 133.14632 \\
\hline
\end{tabular}

Metode yang digunakan dalam penelitian ini adalah pengamatan langsung dan studi literatur. Metode pengamatan langsung merupakan teknik pengumpulan data, dimana peneliti melakukan pengamatan secara langsung ke objek penelitian untuk melihat lebih dekat kegiatan yang dilakukan (Riduwan 2004). Pengamatan langsung dilakukan dengan cara underwater visual census (English et.al 1994). Cara ini dilakukan dengan menyelam dengan peralatan SCUBA pada 2 kedalaman maksimal 10 
meter. Hal ini dikarenakan pertumbuhan terumbu karang optimal berkisar antara 10-15 meter. Jangkauan pengamatan ikan juga mempengaruhi penentuan kedalaman dalam penelitian ini yaitu ke kanan dan kiri masing-masing 2,5 meter untuk ikan berukuran $<35 \mathrm{~cm}$ dan masing-masing 10 meter untuk ukuran ikan yang >35 cm (WWF-Indonesia 2016). Penerapan metode ini diawali dengan membentangkan transek garis sepanjang 50 meter yang diulang sebanyak 5 kali sejajar garis pantai. Data yang dicatat meliputi spesies dan famili ikan, ukuran panjang ikan, serta jumlah banyaknya ikan yang ditemukan (Green dan Bellwood 2009). Selain pengamatan langsung, juga dilakukan studi literatur yaitu mengunakan buku-buku dan literatur lainnya sebagai objek utama (Hadi dan Sutrisno 2001).

Secara keseluruhan, proses pengumpulan data hingga analisis data yang dilakukan untuk mencapai masing masing tujuan berbeda satu sama lain. Tabel 2 menjelaskan terkait pengumpulan data hingga analisis data berdasarkan tujuan penelitian.

Tabel 2 Pengumpulan data

\begin{tabular}{|c|c|c|c|c|}
\hline Tujuan Penelitian & $\begin{array}{c}\text { Data yang } \\
\text { Dibutuhkan }\end{array}$ & $\begin{array}{c}\text { Metode } \\
\text { Penelitian }\end{array}$ & $\begin{array}{c}\text { Cara } \\
\text { Memperoleh }\end{array}$ & Analisis Data \\
\hline $\begin{array}{l}\text { Menghitung } \\
\text { kekayaan jenis dan } \\
\text { indeks ekologi ikan } \\
\text { karang di perairan } \\
\text { pesisir timur Pulau } \\
\text { Kei Besar }\end{array}$ & $\begin{array}{l}\text { Jenis ikan, jumlah } \\
\text { ikan, } \\
\text { keanekaragaman, } \\
\text { keseragaman, } \\
\text { dominansi }\end{array}$ & $\begin{array}{l}\text { Pengamatan } \\
\text { langsung }\end{array}$ & $\begin{array}{l}\text { Underwater } \\
\text { Visual Census }\end{array}$ & $\begin{array}{l}\text { Kekayaan jenis, } \\
\text { keanekaragaman, } \\
\text { keseragaman, } \\
\text { dominansi }\end{array}$ \\
\hline $\begin{array}{l}\text { Mengidentifikasi } \\
\text { kelimpahan ikan } \\
\text { karang yang layak } \\
\text { tangkap di pesisir } \\
\text { timur Pulau Kei } \\
\text { Besar }\end{array}$ & $\begin{array}{l}\text { Jenis ikan, ukuran } \\
\text { ikan, ukuran LM }\end{array}$ & $\begin{array}{l}\text { Pengamatan } \\
\text { langsung, } \\
\text { studi literatur }\end{array}$ & $\begin{array}{l}\text { Underwater } \\
\text { Visual Census, } \\
\text { fishbase dan } \\
\text { literatur } \\
\text { lainnya }\end{array}$ & $\begin{array}{ll}\text { Kelimpahan ikan, } & \text { ikan } \\
\text { persentase } & \text { layak tangkap }\end{array}$ \\
\hline $\begin{array}{l}\text { Menentukan lokasi } \\
\text { penangkapan ikan } \\
\text { karang di perairan } \\
\text { pesisir timur Pulau } \\
\text { Kei Besar }\end{array}$ & $\begin{array}{l}\text { Kekayaan jenis, } \\
\text { persentase layak } \\
\text { tangkap }\end{array}$ & $\begin{array}{l}\text { Pengamatan } \\
\text { langsung, } \\
\text { studi literatur }\end{array}$ & $\begin{array}{l}\text { Underwater } \\
\text { Visual Census, } \\
\text { fishbase dan } \\
\text { literatur } \\
\text { lainnya }\end{array}$ & $\begin{array}{l}\text { Hasil analisis } \\
\text { tujuan } 1 \text { dan } 2\end{array}$ \\
\hline
\end{tabular}

Kekayaan jenis dapat diartikan sebagai jumlah jenis ikan karang (famili) yang terdapat di suatu perairan. Kekayaan jenis ikan yang ditemukan di setiap lokasi pengamatan dapat dihitung dengan persamaan (Odum 1996) sebagai berikut:

Keterangan:

$$
K f=\frac{\sum \text { famili }}{A}
$$

Kf $\quad$ = Kekayaan jenis

$\sum$ famili $=$ Jumlah famili

$A \quad=$ Luas Pengambilan data $\left(1000 \mathrm{~m}^{2}\right)$

Indeks ekologi ikan karang dapat dilihat dari nilai indeks keanekaragaman, keseragaman, dan dominansi komunitas ikan karang tersebut. Keanekaragaman adalah besarnya kerapatan jumlah individu dalam suatu komunitas. Menurut Odum (1971), semakin tinggi nilai $H^{\prime}$ maka keanekaragaman jenis dalam komunitas tersebut semakin besar. sebaliknya, semakin rendah nilai $H^{\prime}$ maka tingkat 
keanekaragaman jenis dalam komunitas tersebut semakin rendah. Keanekaragaman jenis dapat dihitung dengan menggunakan rumus Shannor-Wienner (Kent dan Paddy 1992), sebagai berikut:

$$
H^{\prime}:-\sum_{i=1}^{n} P_{i} \operatorname{Ln} P_{i}
$$

Keterangan:

$H^{\prime} \quad$ : Indeks keanekaragaman

$P i \quad$ : Perbandingan jumlah individu ke spesies ke-i (n) dengan individu (N)

i $\quad: 1,2,3, \ldots . . \mathrm{n}$

Nilai indeks keanekaragaman:

$H^{\prime}<1 \quad$ : Keanekaragaman rendah, miskin, produktivitas sangat rendah sebagai indikasi adanya tekanan yang berat dan ekosistem tidak stabil

$1<H^{\prime}<3$ : Keanekaragaman sedang, produktivitas cukup, kondisi ekosistem cukup seimbang, tekanan ekologis sedang

$H^{\prime}>3$ : Keanekaragaman tinggi, stabilitas ekosistem baik, produktivitas tinggi, tahan terhadap tekanan ekologis

Indeks keseragaman (E) menandakan jumlah individu antar spesies dalam suatu komunitas. Semakin merata penyebaran individu antar spesies, maka keseimbangan ekosistem akan makin meningkat. Kondisi tersebut dilihat dari nilai yang berkisar anatara 0-1. Indeks Keseragaman menggunakan (Odum 1971):

Keterangan:

$$
E=\frac{H^{\prime}}{H_{\max }^{\prime}}
$$

$$
\begin{array}{ll}
E & =\text { Indeks keseragaman } \\
H^{\prime} & =\text { Keseimbangan spesies } \\
H_{\text {max }}^{\prime} & =\text { Indeks keanekaragaman maksimum }=\text { Ln S } \\
S & =\text { Jumlah total macam spesies }
\end{array}
$$

Nilai indeks berkisar antara 0-1 dengan kategori sebagai berikut (Odum 1971):

1. $0<\mathrm{E} \leq 0,4=$ Keseragaman rendah, komunitas tertekan

2. $0,4 \leq \mathrm{E} \leq 0,6=$ Keseragaman sedang, komunitas labil

3. $0,6<\mathrm{E} \leq 1,0=$ Keseragaman tinggi, komunitas stabil

Nilai indeks dominansi berkisar antara 0-1 yang artinya nilai 0 menandakan tidak adanya jenis ikan yang mendominasi, sedangkan nilai 1 menandakan adanya jenis ikan yang mendominasi. Rumus indeks domonasi (C) adalah (Odum, 1971):

$$
C=\sum_{i=1}^{n} p i^{2}
$$

Keterangan:

$$
\begin{aligned}
C & =\text { Indeks dominasi } \\
p i & =\text { Proporsi jumlah individu pada spesies ikan terumbu } \\
i & =1,2,3, . . \mathrm{n}
\end{aligned}
$$

Nilai indeks berkisar antara 0-1 dengan kategori sebagai berikut (Odum 1971):

1. $0<\mathrm{E} \leq 0,4=$ Dominansi rendah, tidak ada ikan yang mendominasi

2. $0,4 \leq \mathrm{E} \leq 0,6=$ Dominansi sedang

3. $0,6<\mathrm{E} \leq 1,0=$ Dominansi tinggi, ada spesies yang mendominansi 
Kelimpahan ikan dapat diartikan sebagai banyaknya jumlah ikan yang ditemukan dalam suatu luasan area pengamatan. Kelimpahan ikan dapat dihitung dengan menggunakan rumus persamaan (Odum 1996) :

Keterangan :

$$
D=\frac{\sum N_{i}}{A}
$$

$D=$ Kelimpahan $\left(\mathrm{Ind} / 1000 \mathrm{~m}^{2}\right)$

$N i=$ Jumlah Individu (Ind)

$A=$ Luas pengambilan data $\left(1000 \mathrm{~m}^{2}\right)$

Ikan karang yang telah diketahui kelimpahannya kemudian dinalisis dengan membandingkan ukurannya dengan ukuran saat pertama kali matang gonad (memijah) atau length at first maturity (Froese dan Pauly 2012). Ukuran length at first maturity (LM) diperoleh melalui Fishbase yang mengacu pada penelitian yang telah dilakukan di wilayah perairan yang sama. Selain berdasarkan metadata fishbase, ukuran length at first maturity (LM) juga dapat dilihat dari jurnal serta literatur lainnya. Hasil ukuran panjang ikan dibandingkan dengan ukuran LM untuk menentukan kategori ikan tersebut sudah layak tangkap atau belum layak tangkap. Ikan karang yang memiliki ukuran lebih panjang daripada ukuran length at first maturity menandakan bahwa ikan karang tersebut sudah layak untuk ditangkap. Persentase dari ikan yang layak tangkap dan ikan yang tidak layak tangkap disajikan dalam bentuk diagram dan dianalisis secara deskriptif.

Menurut Simbolon (2009) ada persyaratan yang harus dipenuhi untuk menjadikan suatu perairan menjadi daerah penangkapan ikan yaitu alat tangkap dapat dioperasikan dengan mudah, perairan dapat dijangkau dengan kapal ikan, serta terdapat sumberdaya ikan yang banyak dan bernilai ekonomis penting. Analisis untuk menentukan daerah penangkapan ikan dilakukan dengan metode skoring terhadap syarat-syarat tersebut. Syarat yang ketiga yaitu terkait sumberdaya ikan ditentukan berdasarkan beberapa parameter yang mengaucu pada Direktur Jenderal Kelautan Pesisir dan PulauPulau kecil (2012). Parameter yang digunakan dalam menganalisis pada penelitian ini dapat dilihat pada Tabel 3:

Tabel 3 Kriteria penilaian daerah penangkapan ikan

\begin{tabular}{rlccc}
\hline \multirow{2}{*}{ No. } & \multicolumn{1}{c}{ Parameter } & \multicolumn{3}{c}{ Kriteria DPI } \\
\cline { 3 - 5 } & & TP & CP & P \\
\hline 1. & Pengoperasian alat tangkap & Tidak & - & Bisa \\
2. & Aksesbilitas & Tertutup & - & Terbuka \\
3. & Keanekaragaman ikan & Rendah & Sedang & Tinggi \\
4. & Keseragaman ikan & Rendah & Sedang & Tinggi \\
5. & Dominansi & Tinggi & Sedang & Rendah \\
6. & Kekayaan jenis & $<10$ jenis & $10-30$ & $>30$ jenis \\
7. & Persentase ikan layak tangkap & Rendah $(<25 \%)$ & Sedang $(25 \%-$ & Tinggi $(250 \%)$ \\
\hline
\end{tabular}

Sumber: Modifikasi Direktur Jenderal Kelautan Pesisir dan Pulau Pulau Kecil (2012) dan Wulandari et al (2017)

Keterangan:

TP : Belum Potensial

$C P \quad$ : Cukup Potensial

$P \quad$ : Potensial 
Penentuan daerah penangkapan ikan berdasarkan tabel 4 dengan cara menghitung dan menjumlahkan total kriteria P (Potensial) dari masing-masing parameternya. Berdasarkan jumlah total kriteria $\mathrm{P}$, dapat dikelompokkan menjadi kategori sebagai berikut:

Belum potensial : terdapat 1 atau 2 parameter menunjukkan kriteria $\mathrm{P}$

Cukup potensial : terdapat 3, 4, atau 5 parameter menunjukkan kriteria $\mathrm{P}$

Potensial : terdapat 6 atau 7 parameter menunjukkan kriteria $\mathrm{P}$

\section{HASIL DAN PEMBAHASAN}

Pulau Kei Besar merupakan salah satu pulau utama dari Kepulauan Kei yang terdiri dari 5 kecamatan yaitu Kecamatan Kei Besar Utara Barat, Kei Besar Utara Timur, Kei Besar, Kei Besar Selatan Barat dan Kei Besar Selatan, namun dalam penelitian ini hanya meliputi 3 kecamatan di sebelah timur Kei Besar. Secara geografis Pulau Kei Besar memiliki batas batas wilayah dengan Pulau Kei Kecil di sebelah barat, Samudera Hindia di sebelah selatan, Laut Arafura di sebelah timur dan Laut banda di sebelah Utara (BPS 2017). Pembagaian luas wilayah lokasi penelitian dapat dilihat pada Tabel 4 :

Tabel 4 Pembagian luas wilayah kecamatan lokasi penelitian

\begin{tabular}{lrrrr}
\hline \multirow{2}{*}{ Kecamatan } & \multirow{2}{*}{ Darat $\left(\mathrm{km}^{2}\right)$} & \multicolumn{2}{c}{ Laut $\left(\mathrm{km}^{2}\right)$} & \multirow{2}{*}{ Total $\left(\mathrm{km}^{2}\right)$} \\
\cline { 3 - 4 } & 112,5818 & $5-4 \mathrm{mil}$ & $4-12 \mathrm{mil}$ & \\
\hline Kei Besar Selatan & 291,8962 & 781,3823 & 1250,3992 & 2323,6777 \\
Kei Besar & 144,7933 & 353,3765 & 955,9798 & 1454,15 \\
Kei Besar Utara Timur & &
\end{tabular}

Sumber: DKP (2010)

Secara umum, luas wilayah perairan di setiap kecamatan lebih luas dibandingkan dengan luas wilayah daratan. Kondisi seperti ini memungkinkan wilayah perairan Pulau Kei Besar menyimpan potensi sumberdaya alam yang lebih besar dibandingkan dengan wilayah daratannya. Hasil pengecekan lapang dan analisis melalui citra satelit yang dilakukan oleh Dinas Perikanan dan Kelautan Kabupaten Maluku Tenggara (2010) menunjukkan bahwa sebagian dari wilayah perairan di pesisir timur Pulau Kei Besar adalah terumbu karang. Perairan Kecamatan Kei Besar Utara Timur memiliki terumbu karang seluas 10,33 km², Kecamatan Kei Besar dengan luas terumbu karang seluas 35,93 km² serta seluas 21,25 $\mathrm{km}^{2}$ terumbu karang yang ada di Kecamatan Kei Besar Utara Timur.

Nelayan di pesisir timur Pulau Kei Besar masih tergolong nelayan tradisional. Mereka menjadikan nelayan bukan sebagai pekerjaan utama, melainkan perkerjaan tambahan. Mereka menangkap ikan hanya untuk memenuhi kebutuhan sehari-hari (konsumsi pribadi). Lokasi penangkapannya pun tidak terlalu jauh dari pantai. Menurut data dari Dinas Kelautan dan Perikanan Kabupaten Maluku Tenggara (2016), terdapat 280 nelayan di Kecamatan Kei Besar Selatan, 721 nelayan di Kecamatan Kei Besar, dan 911 nelayan di Kecamatan Kei Besar Utara Timur.

Sebagian besar nelayan pesisir timur Pulau Kei Besar melakukan aktivitas penangkapan dengan perahu tanpa motor. Sebenarnya terdapat 3 jenis kapal yang dioperasikan oleh masayarakat pesisir timur Pulau Kei Besar, yaitu perahu tak bermotor, perahu motor tempel, dan kapal motor. Berdasarkan data dari Dinas Perikanan Kabupaten Maluku Tenggara tahun 2016, terdapat total 617 nelayan di Kecamatan Kei Besar Selatan dengan 559 nelayan dengan perahu tanpa motor, 53 nelayan dengan perahu motor tempel, dan 5 nelayan dengan kapal bermotor. Sebanyak 842 nelayan di Kecamatan Kei Besar dengan 689 diantaranya menggunakan perahu tanpa motor, 130 nelayan menggunakan perahu motor tempel, dan 23 nelayan menggunakan kapal motor dan nelayan di Kecamatan Kei Besar Utara Timur berjumlah 580 nelayan. Nelayan yang mengoperasikan perahu tanpa motor sebanyak 450 nelayan, perahu motor tempel 119 nelayan, serta 11 nelayan yang menggunakan kapal motor. 
Alat tangkap merupakan salah satu unit penangkapan ikan dalam operasi penangkapan ikan. Berdasarkan data sekunder yang didapat dari Dinas Kelautan dan Perikanan Kabupaten Maluku Tenggara tahun 2010, terdapat 4 alat tangkap yang sering digunakan oleh masyarakat sekitar Pulau Kei Besar. Empat alat tangkap tersebut adalah jaring (jaring hanyut, jaring tetap, dan jaring lingkar), bubu, pancing ulur, pengumpul (pengumpul kerang dan pengumpul teripang), serta alat tangkap lainnya. Namun untuk area terumbu karang, hanya alat tangkap bubu dan pancing yang ramah lingkungan. Data terkait alat tangkap yang nelayan Pesisir Timur Kei Besar gunakan dalam menangkap ikan di area terumbu karang dapat dilihat pada Tabel 5.

Tabel 5 Jumlah alat tangkap yang digunakan di setiap lokasi pengamatan

\begin{tabular}{lcc}
\hline Desa/ Dusun & Bubu & Pancing \\
\hline Kilwat & 3 & 96 \\
Weduar & 2 & 69 \\
Ohoirenan & 2 & 93 \\
Ohoiwait & 4 & 54 \\
Ngufit Bawah & - & 54 \\
Yamtel & 3 & 75 \\
Fako & 3 & 66 \\
Hollat & 1 & 96 \\
Ohoifau & - & 83 \\
\hline
\end{tabular}

Sumber: Dinas Kelautan dan Perikanan Kabupaten Maluku Tenggara (2010)

Hasil perikanan yang sering ditangkap oleh masayarakat pesisir timur Kei Besar antara lain ikan baronang, lencam, kerapu, kakap merah, mata bulan, dan lainnya. Musim penangkapan ikan karang di Pulau Kei Besar hampir merata sepanjang tahun.

\section{Kekayaan Jenis dan Indeks Ekologi Ikan Karang di Pesisir Timur Pulau Kei Besar}

Berdasarkan hasil pengamatan yang dilakukan di pesisir timur Pulau Kei Besar yang melibatkan tiga kecamatan, didapatkan sebanyak 24870 individu (15338 target) ikan terumbu yang termasuk ke dalam 33 famili (14 target), 100 genus (58 target), serta 309 spesies (176 target). Adapun 4 dari 33 famili yang menjadi famili ikan target paling banyak dan ditemukan di semua lokasi pengamatan. Empat famili tersebut adalah Famili Caesionidae, Acanthuridae, Lutjanidae, dan Labridae. Kondisi ini dapat disebabkan karena tipe perairan pesisir timur Pulau Kei Besar sesuai dengan habitat famili-famili tersebut yaitu berkontur reef flat (terumbu karang dengan kontur datar) dan beberapa lokasi pengamatan merupakan gosong terumbu (patch reef). Menurut Lieske dan Myers (1994), Famili Caesionidae, khususnya Genus Pterocaesio dan Famili Acanthuridae banyak dijumpai di daerah reef flat sedangkan Famili Lutjanidae banyak ditemukan di daerah patch reef (gosong terumbu). Famili Labridae menjadi salah satu famili ikan karang target yang ditemukan di merata di seluruh lokasi pengamatan. Hal ini dikarenakan jumlah spesies dari Famili Labridae paling banyak diantara familifamili lainnya (untuk kategori ikan target) sehingga kemungkinan untuk ditemukannya ikan dari famili ini lebih besar dibandingkan dengan famili lainnya. Selain keempat famili yang telah disebutkan, masih ada beberapa famili ikan target yang ditemukan namun tidak di ditemukan di setiap lokasi pengamatan seperti ikan dari Famili Scaridae, Serranidae, Nemipteridae, Siganidae, Lethrinidae Haemulidae, Carangidae, Scrombidae, Sphyraenidae, dan Dasyatidae. Hal tersebut menandakan bahwa 14 dari 15 famili ikan kategori target yang telah ditetapkan oleh Direktur Jendral Kelautan, Pesisir, dan Pulau Pulau Kecil Nomor Kep.44/KP3K/2012 dapat ditemukan di perairan pesisir timur Pulau Kei Besar. 


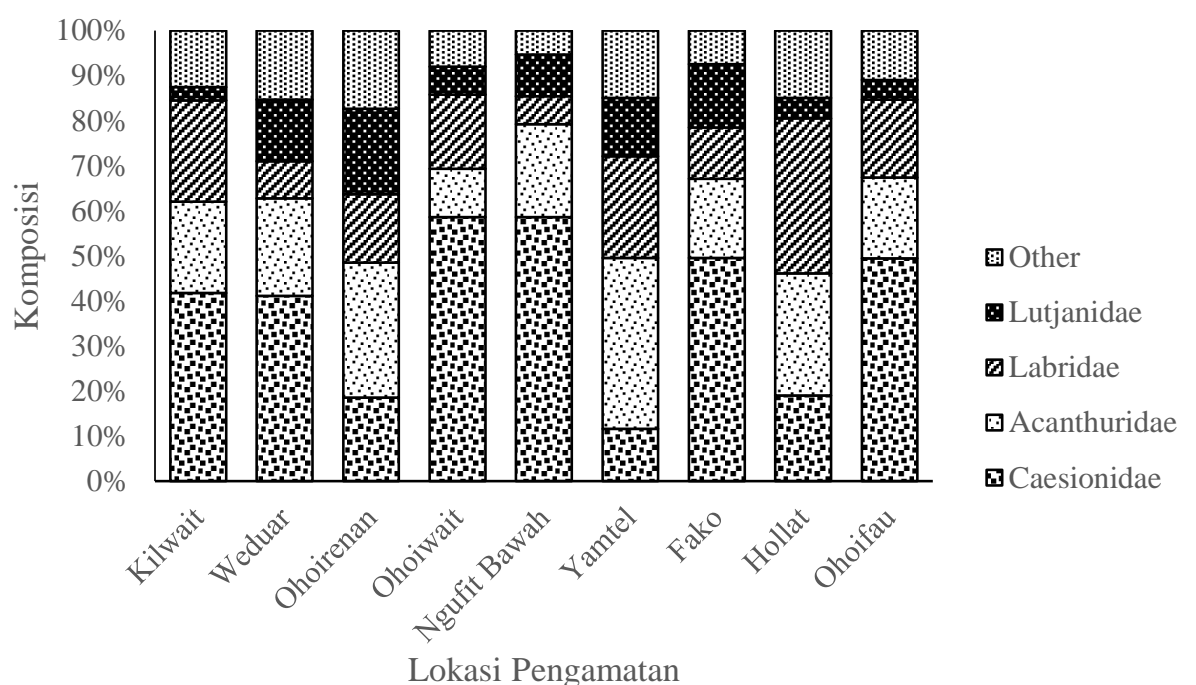

Gambar 2 Persentase jumlah individu per famili yang paling banyak ditemukan

Dapat dilihat pada Gambar 2 bahwa Famili Caesionidae merupakan famili yang paling banyak ditemukan dan merata penyebarannya di perairan pesisir timur Pulau Kei Besar. Ikan yang termasuk ke dalam famili ini seperti ikan ekor kuning dan ikan pisang-pisang. Ikan tersebut biasa ditemukan secara berkelompok dengan jumlah sekitar 100 ikan dalam satu kelompoknya. Ikan ini merupakan ikan yang memiliki fungsi sebagai ikan target, artinya ikan ekor kuning dan/atau ikan pisang-pisang biasa dijadikan sebagai target tangkapan nelayan untuk konsumsi. Famili Acanthuridae atau ikan dengan nama lokal ikan kulit pasir juga banyak ditemukan di perairan pesisir timur Pulau Kei Besar. Acanthuridae hidup pada kelompok yang tidak terlalu besar di kolom hingga dasar perairan. Ikan dari Famili Lutjanidae atau lebih dikenal dengan ikan kakap juga cukup banyak ditemukan di pesisir timur Kei Besar dan memiliki ukuran yang cukup besar sekitar 20-50 cm. Famili Labridae juga ditemukan merata di semua lokasi pengamatan. Ikan ini biasa ditangkap untuk dijadikan ikan hias oleh para nelayan.

Indeks ekologi yang terdiri dari indeks keanekaragaman $(\mathrm{H})$, indeks keseragaman (E), dan indeks dominansi (C) merupakan nilai yang dapat digunakan untuk menilai suatu kondisi dimana dalam hal ini adalah komunitas ikan karang. Nilai indeks keanekaragaman yang rendah dapat menunjukkan bahwa semua individu berasal dari satu spesies, sedangkan ketika nilai keseragaman rendah jika individu ditemukan dari spesies yang sama. Nilai keseragaman berkisar antara 0-1 dan semakin kecil nilai keseragaman maka semakin kecil pulau keseragaman dari suatu komunitas tersebut. Nilai indeks dominansi digunakan untuk melihat apakah ada suatu organisme atau suatu spesies yang mendominasi atau tidak. Gambar 3 menunjukkan nilai indeks keanekaragaman, indeks keseragaman, dan indeks dominansi di perairan pesisir timur Pulau Kei Besar.

Berdasarkan Gambar 3, indeks keanekaragaman ikan karang di semua lokasi pengamatan berkisar antara 1.86 hingga 2.56. Hal tersebut menandakan bahwa keanekaragaman ikan di pesisir timur Pulau Kei Besar adalah sedang. Keseragaman ikan karang di pesisir timur Pulau Kei Besar menunjukkan hasil yang tinggi yaitu berkisar antara 0.62-0.80 dan dominansi ikan karang di pesisir timur Pulau Kei Besar termasuk rendah. Hal ini ditandai dengan nilai indeks dominansi yang berkisar antara 0.14 hingga 0.33 . 


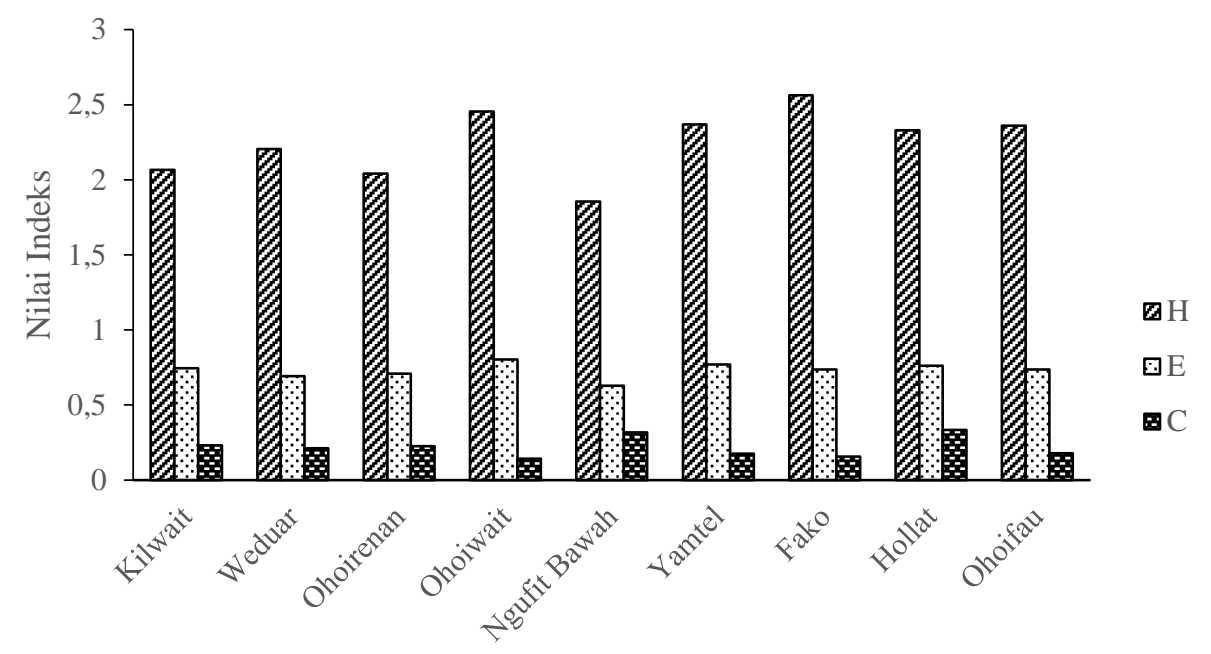

Lokasi Pengamatan

Gambar 3 Indeks ekologi ikan karang di pesisir timur Pulau Kei Besar

Keanekaragaman yang sedang menandakan produktivitas ikan karang di perairan tersebut cukup baik dan kondisi ekosistemnya cukup seimbang. Keanekaragaman ikan karang tertinggi berada di lokasi Fako, sedangkan keanekaragaman ikan terendah berada di lokasi Ngufit Bawah. Komunitas ikan karang di perairan tersebut juga dapat dikatakan stabil, ditandai dengan nilai keseragaman ikan karang yang tinggi (Odum 1996). Keseragaman ikan yang tinggi ini menunjukkan bahwa persebaran jumlah individu ikan karang masing-masing spesies merata. Hal ini menandakan bahwa diperairan pesisir timur Pulau Kei Besar tidak ada spesies ikan yang mendominasi dan dibuktikan dengan nilai dominansi yang rendah.

Kondisi perairan yang ideal adalah perairan yang memiliki indeks ekologi yang baik, yaitu memiliki nilai keanekaragaman tinggi, keseragaman tinggi, dan dominansi yang rendah, seperti hal nya pada penelitian Nasir M et al (2017) di perairan Pulau Batee, Kabupaten Aceh Besar. Kondisi seperti ini menandakan bahwa perairan tersebut kompleks, yang menyediakan berbagai makanan dalam jumlah yang cukup serta memiliki terumbu karang yang baik sebagai tempat tinggal sehingga berbagai spesies ikan mendiami perairan tersebut. Kurang adanya tekanan baik dari lingkungan tempat organisme hidup maupun aktivitas langsung dari manusia juga hal yang menyebabkan kondisi lingkungan perairan tersebut baik. Jumlah individu antar spesies yang merata juga mempengaruhi kestabilan ekosistem di perairan tersebut. Hal ini berarti tidak ada spesies yang mendominasi. Ketika terdapat spesies yang mendominasi dan seandainya terjadi penangkapan yang berlebih atau kepunahan pada spesies ikan tersebut, maka hal itu akan mempengaruhi trofik level sehingga kestabilan ekosistem tersebut akan terganggu.

\section{Identifikasi Kelimpahan Ikan Karang yang Layak Tangkap di Pesisir Timur Pulau Kei Besar}

Menurut English et al (1994) ikan karang terbagi menjadi tiga kategori berdasarkan fungsionalnya yaitu ikan mayor, ikan target, dan ikan indikator. Ikan mayor merupakan ikan yang banyak dijumpai di ekosistem terumbu karang dan memiliki jumlah spesies maupun individu cukup banyak. Ikan target adalah ikan yang memiliki nilai ekonomis tinggi sebagai ikan hias maupun ikan konsumsi sehingga sering kali dijadikan target penangkapan oleh nelayan, sedangkan ikan indikator merupakan ikan yang memiliki keterkaitan cukup erat dengan ekosistem terumbu karang sehingga dijadikan indikator kondisi suatu ekosistem terumbu karang.

Kelompok ikan target telah ditetapkan melalui keputusan Direktur Jendral Kelautan, Pesisir, dan Pulau Pulau Kecil Nomor Kep.44/KP3K/2012 tentang Pedoman Teknik Evaluasi Efektivitas Pengelolaan Kawasan Konservasi Perairan, Pesisir, dan Pulau -Pulau Kecil. Ikan yang dijadikan target 
tangkapan nelayan lokal atau komersial adalah ikan dari famili Acanthuridae, Scaridae, Siganidae, Lutjanidae, Labridae, Seranidae, Lethrinidae, Carangidae, Scrombidae, Caesionidae, Haemulidae, Nemipteridae, Sphyraenidae, Carcharnidae, dan Dasyatidae. Gambar 4 dibawah ini menunjukkan kelimpahan ikan di pesisir timur Pulau Kei Besar berdasarkan kategori fungsionalnya. Kelimpahan ikan sendiri dapat diartikan sebagai banyaknya jumlah individu ikan yang didapatkan dalam suatu luasan area pengamatan, yang mana dalam penelitian ini luas area pengamatannya adalah $1000 \mathrm{~m}^{2}$.

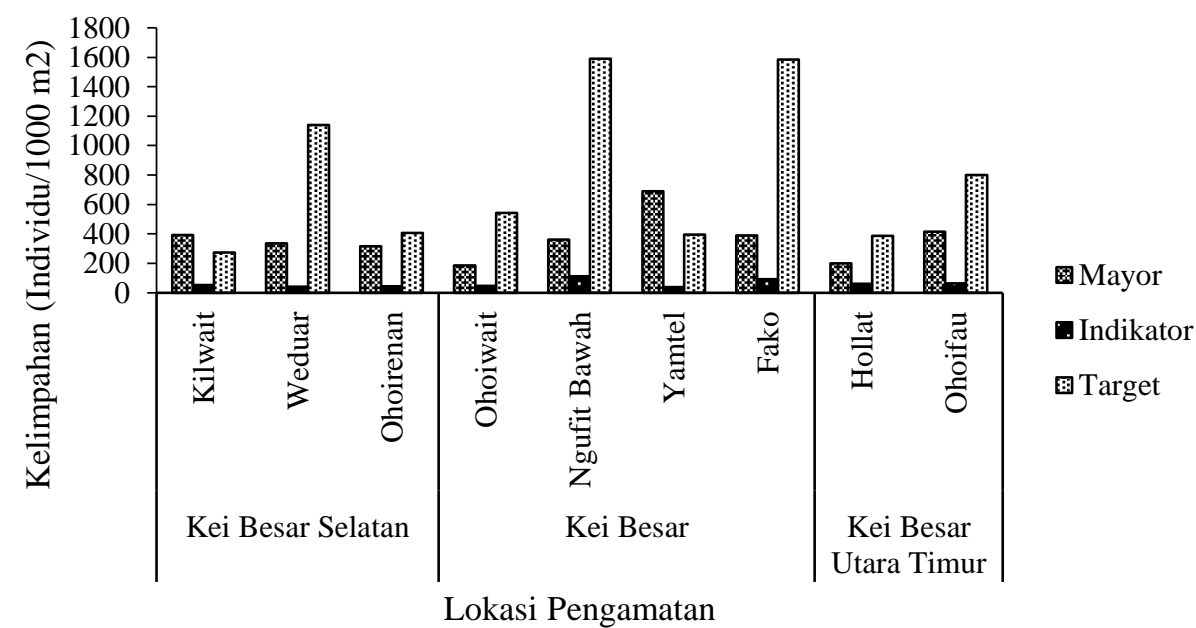

Gambar 4 Kelimpahan masing masing kategori fungsioanl ikan

Gambar 4 menunjukkan bahwa ikan target memiliki kelimpahan yang paling tinggi di hampir seluruh lokasi pengamatan, kecuali lokasi Kilwait dan Yamtel. Hal ini berarti ikan yang memiliki fungsi sebagai ikan target banyak ditemukan dan mendominasi hampir di seluruh perairan pesisir timur Pulau Kei Besar. Keberadaan ikan target ini berkaitan dengan banyaknya bentuk pertumbuhan karang yang mengerak (encrusting) sehingga menyediakan makanan yang cukup banyak bagi ikan kategori target sedangkan perairan Kilwait didominasi oleh karang lunak ( soft coral) yang menyebabkan melimpahnya ikan karang kategori mayor. Kelimpahan ikan kategori target yang ditemukan di pesisir timur Pulau Kei Besar dapat dilihat pada Gambar 5.

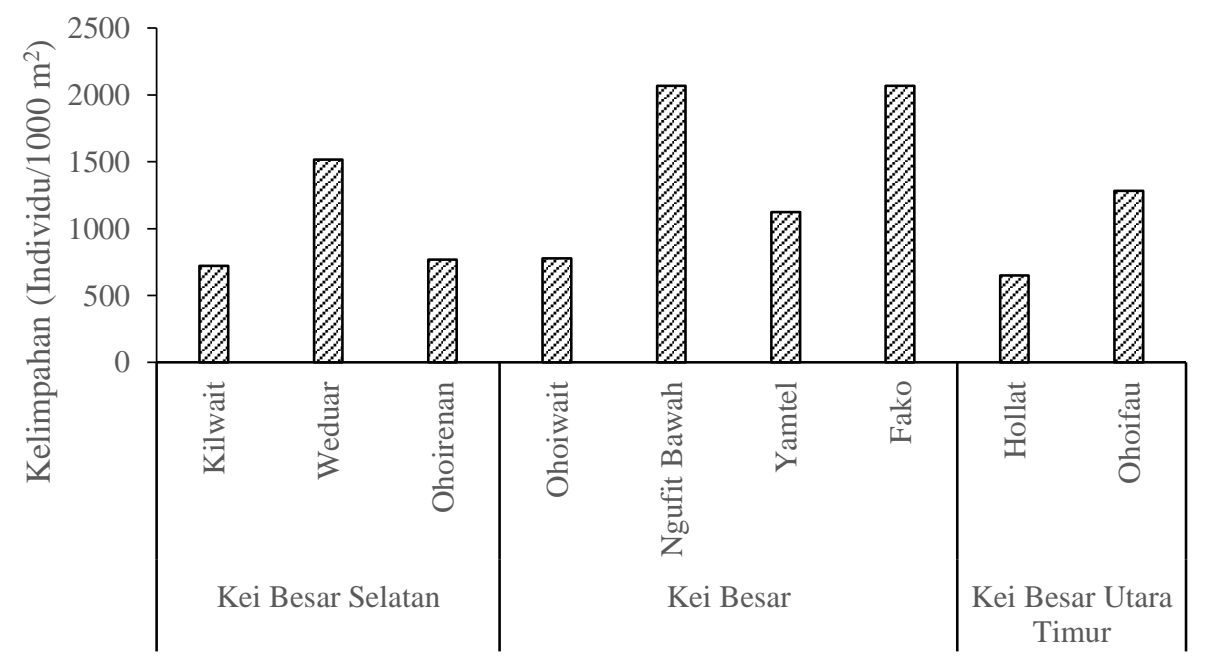

Lokasi Pengamatan

Gambar 5 Kelimpahan ikan di setiap lokasi pengamatan 
Berdasarkan Gambar 5 dapat dilihat bahwa kelimpahan ikan tertinggi berada di lokasi Fako senilai 2069 individu/1000 $\mathrm{m}^{2}$ sedangkan kelimpahan ikan terendah berada di lokasi Hollat sebesar 650 individu/1000 $\mathrm{m}^{2}$. Keberadaan ikan ini dipengaruhi oleh beberapa faktor, salah satunya adalah rugositas atau kompleksitas habitat (habitat complexity). Seperti yang dinyatakan oleh Mujiyanto dan Hartati (2011) bahwa tipe terumbu karang sebagai habitat menentukan jenis dan kelimpahan ikan terumbu. Afinitas ikan karang terhadap habitatnya dapat ditentukan oleh kompleksitas habitat (habitat complexity). Lokasi Fako dengan kelimpahan ikan karang target tertinggi memiliki bentuk habitat yang cukup kompleks. Banyak relung relung terumbu karang yang menjadi tempat tinggal bagi ikan karang tersebut. Selain itu rugositas yang baik dapat menyediakan sumber makanan bagi biota yang ada dalam ekosistem tersebut. Berbeda dengan Fako, kelimpahan ikan pada lokasi Hollat yang rendah dapat disebabkan karena rusaknya habitat ekosistem terumbu karang yang ada di lokasi tersebut. Berdasarkan pengamatan yang telah dilakukan pada lokasi Hollat banyak ditemukan patahan-patahan karang serta karang mati. Kondisi tersebut tentu saja mempengaruhi keberadaan ikan karang yang membutuhkan ekosistem terumbu karang untuk berasosiasi dalam hidupnya.

Jumlah ikan yang banyak atau kelimpahan ikan yang tinggi belum dapat dikatakan bahwa ikan tersebut layak untuk ditangkap. Namun perlu memperhatikan ukuran individu ikan tersebut. Ikan karang dapat dikatakan layak untuk ditangkap apabila memiliki ukuran panjang lebih besar daripada ukuran pertama kali matang gonad (length at first maturity).

Selama pengamatan yang dilakukan di pesisir timur Pulau Kei Besar ditemukan 309 spesies ikan karang, 176 diantaranya adalah kategori ikan target. Namun tidak semua spesies ikan telah diketahui ukuran pertama kali matang gonad, hanya 39 dari 176 ikan kategori target yang telah diketahui ukuran pertama kali matang gonadnya. Sehingga dapat dikatakan hanya 22\% dari total ikan target yang ditemukan di Pesisir Timur Pulau Kei Besar telah diketahui panjang pertama kali matang gonadnya, sedangkan 78\% ikan target belum diketahui panjang pertama kali matang gonadnya. Tabel 6 menyajikan kelimpahan ikan karang target beserta persentase jumlah ikan tersebut yang sudah layak untuk ditangkap.

Tabel 6 Kelimpahan ikan karang yang sudah layak tangkap

\begin{tabular}{clccc}
\hline Lokasi & \multicolumn{1}{c}{ Spesies } & $\sum$ (Ind) & I Ikan > LM & Layak Tangkap \\
\hline Kilwait & Acanthurus leucosternon & 2 & 0 & $0.00 \%$ \\
& Chlorurus sordidus & 40 & 16 & $40.00 \%$ \\
& Halichoeres hortulanus & 8 & 8 & $100.00 \%$ \\
& Lethrinus lentjan & 1 & 1 & $100.00 \%$ \\
& Lutjanus rivulatus & 2 & 2 & $100.00 \%$ \\
& Monotaxis grandoculis & 4 & 0 & $0.00 \%$ \\
& Pterocaesio pisang & 175 & 105 & $60.00 \%$ \\
& Siganus guttatus & 1 & 0 & $0.00 \%$ \\
& Thalassoma hardwicke & 44 & 32 & $72.00 \%$ \\
& & & & \\
& Acanthurus lineatus & 132 & 52 & $39.40 \%$ \\
& Acanthurus nigricauda & 60 & 44 & $73.30 \%$ \\
& Cephalopholis boenak & 8 & 8 & $100.00 \%$ \\
& Chlorurus sordidus & 8 & 8 & $100.00 \%$ \\
& Halichoeres hortulanus & 2 & 2 & $100.00 \%$ \\
& Lethrinus lentjan & 128 & 40 & $31.25 \%$ \\
& Lutjanus bohar & 37 & 0 & $0.00 \%$ \\
& Lutjanus ehrenbergii & 7 & 6 & $85.71 \%$ \\
\hline
\end{tabular}




\begin{tabular}{|c|c|c|c|c|}
\hline Lokasi & Spesies & $\sum($ Ind $)$ & $\sum$ Ikan $>$ LM & Layak Tangkap \\
\hline & Lutjanus fulviflamma & 48 & 48 & $100.00 \%$ \\
\hline & Lutjanus fulvus & 40 & 40 & $100.00 \%$ \\
\hline & Lutjanus gibbus & 4 & 4 & $100.00 \%$ \\
\hline & Lutjanus rivulatus & 14 & 10 & $71.43 \%$ \\
\hline & Pterocaesio pisang & 95 & 40 & $42.10 \%$ \\
\hline & Pterocaesio tile & 686 & 686 & $0.00 \%$ \\
\hline & Siganus guttatus & 3 & 3 & $100.00 \%$ \\
\hline \multirow[t]{16}{*}{ Ohoirenan } & Acanthurus lineatus & 1 & 0 & $0.00 \%$ \\
\hline & Aprion virescens & 62 & 16 & $25.81 \%$ \\
\hline & Chlorurus sordidus & 4 & 4 & $100.00 \%$ \\
\hline & Halichoeres hortulanus & 32 & 20 & $62.50 \%$ \\
\hline & Lethrinus harak & 40 & 24 & $60.00 \%$ \\
\hline & Lutjanus bohar & 88 & 0 & $0.00 \%$ \\
\hline & Lutjanus carponotatus & 1 & 1 & $100.00 \%$ \\
\hline & Lutjanus fulvus & 24 & 0 & $0.00 \%$ \\
\hline & Lutjanus gibbus & 48 & 0 & $0.00 \%$ \\
\hline & Lutjanus vitta & 1 & 1 & $100.00 \%$ \\
\hline & Monotaxis grandoculis & 32 & 0 & $0.00 \%$ \\
\hline & Pterocaesio digramma & 30 & 0 & $0.00 \%$ \\
\hline & Pterocaesio pisang & 30 & 30 & $100.00 \%$ \\
\hline & Pterocaesio tile & 30 & 0 & $0.00 \%$ \\
\hline & Siganus guttatus & 4 & 4 & $100.00 \%$ \\
\hline & Thalassoma hardwicke & 48 & 48 & $100.00 \%$ \\
\hline \multirow[t]{17}{*}{ Ohoiwait } & Acanthurus leucosternon & 3 & 0 & $0.00 \%$ \\
\hline & Acanthurus nigricauda & 4 & 4 & $100.00 \%$ \\
\hline & Aprion virescens & 3 & 3 & $100.00 \%$ \\
\hline & Cephalopholis boenak & 1 & 1 & $100.00 \%$ \\
\hline & Chlorurus sordidus & 8 & 4 & $50.00 \%$ \\
\hline & Epinephelus merra & 20 & 20 & $100.00 \%$ \\
\hline & Halichoeres hortulanus & 28 & 28 & $100.00 \%$ \\
\hline & Halichoeres marginatus & 16 & 16 & $100.00 \%$ \\
\hline & Lethrinus harak & 6 & 0 & $0.00 \%$ \\
\hline & Lethrinus lentjan & 1 & 1 & $100.00 \%$ \\
\hline & Lutjanus bohar & 5 & 5 & $100.00 \%$ \\
\hline & Lutjanus fulviflamma & 1 & 1 & $100.00 \%$ \\
\hline & Lutjanus fulvus & 3 & 3 & $100.00 \%$ \\
\hline & Lutjanus gibbus & 19 & 6 & $31.58 \%$ \\
\hline & Lutjanus rivulatus & 10 & 10 & $100.00 \%$ \\
\hline & Lutjanus russelli & 6 & 6 & $100.00 \%$ \\
\hline & Monotaxis grandoculis & 2 & 0 & $0.00 \%$ \\
\hline
\end{tabular}




\begin{tabular}{|c|c|c|c|c|}
\hline Lokasi & Spesies & $\sum($ Ind $)$ & $\sum$ Ikan $>$ LM & Layak Tangkap \\
\hline & Pterocaesio caulaurea & 15 & 15 & $100.00 \%$ \\
\hline & Pterocaesio digramma & 100 & 0 & $0.00 \%$ \\
\hline & Pterocaesio marri & 37 & 37 & $100.00 \%$ \\
\hline & Pterocaesio pisang & 15 & 14 & $93.33 \%$ \\
\hline & Pterocaesio tile & 341 & 40 & $11.73 \%$ \\
\hline & Pterocaesio trilineata & 79 & 63 & $79.75 \%$ \\
\hline & Siganus guttatus & 5 & 5 & $100.00 \%$ \\
\hline & Taeniura lymma & 4 & 4 & $100.00 \%$ \\
\hline & Thalassoma hardwicke & 56 & 52 & $92.86 \%$ \\
\hline \multirow[t]{7}{*}{ Ngufit bawah } & Acanthurus lineatus & 116 & 40 & $34.48 \%$ \\
\hline & Acanthurus nigricauda & 20 & 20 & $100.00 \%$ \\
\hline & Cephalopholis boenak & 2 & 1 & $50.00 \%$ \\
\hline & Chlorurus sordidus & 5 & 1 & $20.00 \%$ \\
\hline & Lutjanus bohar & 191 & 191 & $100.00 \%$ \\
\hline & Pterocaesio pisang & 30 & 30 & $100.00 \%$ \\
\hline & Pterocaesio tile & 1475 & 2 & $0.14 \%$ \\
\hline \multirow[t]{12}{*}{ Yamtel } & Acanthurus lineatus & 29 & 17 & $58.62 \%$ \\
\hline & Acanthurus nigricauda & 7 & 1 & $14.29 \%$ \\
\hline & Cephalopholis boenak & 1 & 1 & $100.00 \%$ \\
\hline & Chlorurus sordidus & 8 & 8 & $100.00 \%$ \\
\hline & Halichoeres hortulanus & 64 & 40 & $62.50 \%$ \\
\hline & Lutjanus bohar & 39 & 39 & $100.00 \%$ \\
\hline & Lutjanus ehrenbergii & 44 & 0 & $0.00 \%$ \\
\hline & Lutjanus gibbus & 12 & 0 & $0.00 \%$ \\
\hline & Lutjanus rivulatus & 15 & 0 & $0.00 \%$ \\
\hline & Pterocaesio tile & 130 & 130 & $100.00 \%$ \\
\hline & Stethojulis trilineata & 4 & 4 & $100.00 \%$ \\
\hline & Thalassoma hardwicke & 48 & 28 & $58.33 \%$ \\
\hline \multirow[t]{13}{*}{ Fako } & Acanthurus lineatus & 73 & 73 & $100.00 \%$ \\
\hline & Acanthurus nigricauda & 44 & 38 & $86.36 \%$ \\
\hline & Chlorurus sordidus & 1 & 1 & $100.00 \%$ \\
\hline & Epinephelus merra & 4 & 4 & $100.00 \%$ \\
\hline & Halichoeres hortulanus & 48 & 28 & $58.33 \%$ \\
\hline & Lutjanus bohar & 66 & 66 & $100.00 \%$ \\
\hline & Lutjanus ehrenbergii & 8 & 8 & $100.00 \%$ \\
\hline & Lutjanus fulviflamma & 41 & 3 & $7.32 \%$ \\
\hline & Lutjanus fulvus & 5 & 0 & $0.00 \%$ \\
\hline & Lutjanus gibbus & 31 & 3 & $9.68 \%$ \\
\hline & Pterocaesio pisang & 330 & 310 & $93.94 \%$ \\
\hline & Pterocaesio tile & 1065 & 20 & $1.88 \%$ \\
\hline & Scarus frenatus & 4 & 4 & $100.00 \%$ \\
\hline
\end{tabular}




\begin{tabular}{|c|c|c|c|c|}
\hline Lokasi & Spesies & $\sum($ Ind $)$ & $\sum$ Ikan $>$ LM & Layak Tangkap \\
\hline & Scarus ghobban & 3 & 3 & $100.00 \%$ \\
\hline & Taeniura lymma & 1 & 1 & $100.00 \%$ \\
\hline & Thalassoma hardwicke & 80 & 72 & $90.00 \%$ \\
\hline & Variola louti & 12 & 0 & $0.00 \%$ \\
\hline \multirow[t]{8}{*}{ Hollat } & Acanthurus lineatus & 9 & 9 & $100.00 \%$ \\
\hline & Chlorurus sordidus & 1 & 0 & $0.00 \%$ \\
\hline & Epinephelus merra & 5 & 5 & $100.00 \%$ \\
\hline & Halichoeres hortulanus & 48 & 24 & $50.00 \%$ \\
\hline & Lutjanus bohar & 2 & 0 & $0.00 \%$ \\
\hline & Pterocaesio pisang & 200 & 200 & $100.00 \%$ \\
\hline & Sphyraena barracuda & 1 & 1 & $100.00 \%$ \\
\hline & Thalassoma hardwicke & 28 & 8 & $28.57 \%$ \\
\hline \multirow[t]{14}{*}{ Ohoifau } & Acanthurus leucosternon & 1 & 1 & $100.00 \%$ \\
\hline & Acanthurus lineatus & 4 & 4 & $100.00 \%$ \\
\hline & Epinephelus merra & 4 & 4 & $100.00 \%$ \\
\hline & Halichoeres hortulanus & 56 & 14 & $25.00 \%$ \\
\hline & Lethrinus harak & 12 & 12 & $100.00 \%$ \\
\hline & Lutjanus bohar & 1 & 1 & $100.00 \%$ \\
\hline & Lutjanus fulviflamma & 56 & 36 & $64.29 \%$ \\
\hline & Lutjanus fulvus & 3 & 3 & $100.00 \%$ \\
\hline & Monotaxis grandoculis & 12 & 12 & $100.00 \%$ \\
\hline & Perocaesio lativittata & 200 & 200 & $100.00 \%$ \\
\hline & Pterocaesio pisang & 400 & 400 & $100.00 \%$ \\
\hline & Pterocaesio tile & 284 & 200 & $70.42 \%$ \\
\hline & Siganus guttatus & 72 & 72 & $100.00 \%$ \\
\hline & Thalassoma hardwicke & 53 & 21 & $39.62 \%$ \\
\hline
\end{tabular}

Keterangan: LM: Length at First Maturity

Tabel 6 menunjukkan beberapa spesies ikan yang termasuk kedalam kategori ikan target di setiap lokasi pengamatan telah memiliki ukuran yang layak untuk ditangkap karena memiliki ukuran panjang yang sudah melebihi ukuran pertama kali matang gonad. Namun masih ada beberapa spesies ikan yang belum layak untuk ditangkap. Perbadingan antara ikan yang sudah layak tangkap dan yang belum layak tangkap dapat dilihat pada Gambar 6 berikut ini.

Berdasarkan Gambar 6, Hollat memiliki komposisi yang sama antara jumlah spesies ikan yang sudah layak tangkap dan yang belum layak tangkap. Empat lokasi memiliki jumlah spesies ikan yang layak tangkap lebih banyak dibandingkan dengan ikan yang tidak layak tangkap. Lokasi tersebut adalah Weduar, Ohoiwait, Fako, dan Ohoifau sedangkan 3 lokasi yaitu Ohoirenan, Ngufit Bawah, dan Yamtel memiliki jumlah spesies ikan layak tangkap lebih sedikit dibandingkan dengan yang tidak layak tangkap. 


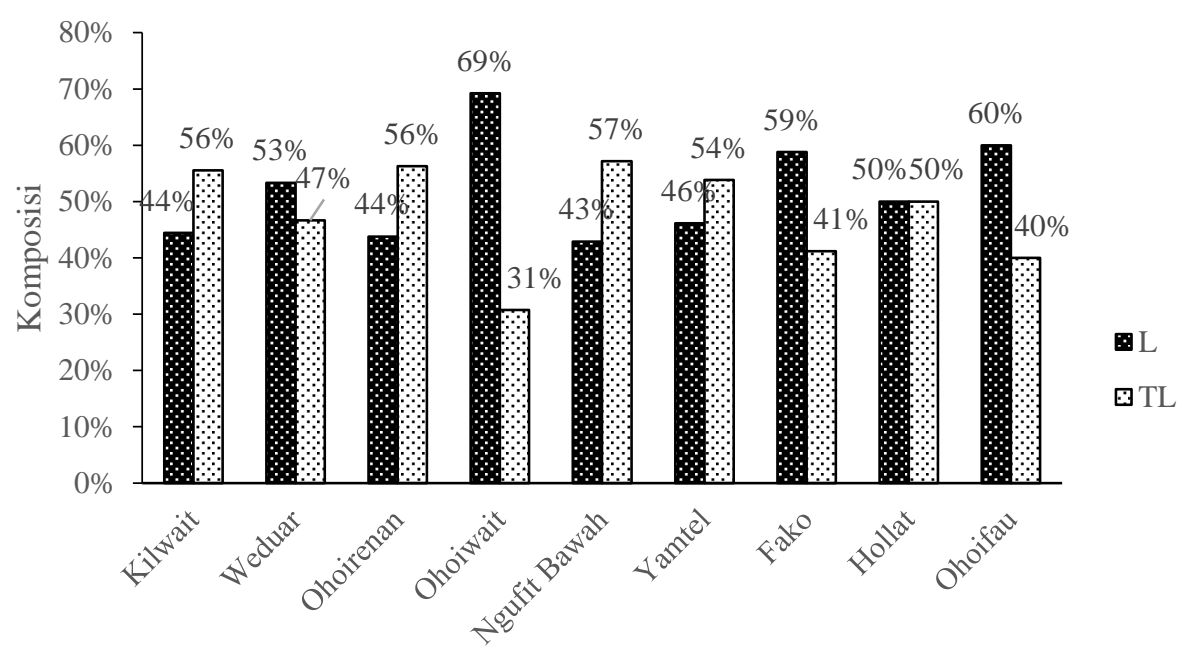

Lokasi Pengamatan

Gambar 6 Perbandingan ikan target yang layak tangkap dan belum layak tangkap

Menurut Simbolon (2009), syarat suatu perairan menjadi daerah penangkapan ikan adalah dapat dioperasikannya alat tangkap dengan mudah, dapat diakses atau dijangkau, dan terdapat sumberdaya ikan bernilai ekonomis tinggi. Berdasarkan pengamatan yang dilakukan di pesisir timur Pulau Kei Besar, seluruh lokasi pengamatan dapat diakses. Sehingga untuk persyaratan pertama, seluruh lokasi pengamatan memenuhi untuk menjadi daerah penangkapan ikan. Dari sisi dapat dioperasikannya alat tangkap, seluruh lokasi pengamatan memiliki substrat terumbu karang sehingga tidak semua alat tangkap dapat dioperasikan. Namun masih tegolong mudah dioperasikan alat tangkap dengan catatan hanya alat tangkap tertentu saja, seperti bubu, panah, dan pancing. Oleh karena itu, dari persyaratan dapat dioperasikannya alat tangkap di perairan tersebut, seluruh lokasi pengamatan di pesisir timur Pulau Kei Besar memenuhi syarat sehingga dapat dikategorikan sebagai daerah penangkapan ikan karang. Persayaratan ketiga yaitu terdapat sumberdaya ikan yang menunjukkan hasil yang berbeda setiap lokasi pengamatan, sehingga diperlukan perhitungan untuk mengkategorikan apakah lokasi tersebut berpotensi untuk dijadikan daerah penangkapan ikan.

Tabel 7 menunjukkan perhitungan terhadap kriteria yang dijadikan parameter daerah penangkapan ikan beserta jenis (spesies) ikan karang yang potensial di setiap lokasi pengamatan. Penjelasan terkait kriteria yang dijadikan parameter daerah penangkapan ikan adalah sebagai berikut:

1. Dapat dioperasikan alat tangkap: seluruh lokasi pengamatan berkategori potensial

2. Aksesbilitas: seluruh lokasi pengamatan berkategori potensial

3. Keanekaragaman: berdasarkan Tabel 3 dan Gambar 3 seluruh lokasi pengamatan memiliki nilai keanekaragaman yang sedang, sehingga dikategorikan sebagai daerah yang cukup potensial

4. Keseragaman: berdasarkan Tabel 3 dan Gambar 3 seluruh lokasi pengamatan memiliki nilai keseragaman yang tinggi, sehingga dikategorikan sebagai daerah yang potensial

5. Dominansi: berdasarkan Tabel 3 dan Gambar 3 seluruh lokasi pengamatan memiliki nilai dominansi yang rendah, sehingga dikategorikan sebagai daerah penangkapan ikan yang potensial

6. Kekayaan jenis: masing-masing lokasi pengamatan menunjukkan hasil yang berbeda

7. Persentase layak tangkap: masing-masing lokasi pengamatan menunjukkan hasil yang berbeda.

Hasil pada Tabel 7 tersebut menunjukkan bahwa lokasi perairan Kilwait, Weduar, Ohoirenan, Ngufit Bawah, Yamtel, Hollat, dan Ohoifau merupakan perairan yang cukup potensial untuk menangkap ikan karang serta perairan Ohoiwait dan Fako merupakan perairan yang potensial untuk menangkap ikan karang. Lokasi penangkapan ikan yang potensial di pesisir timur Pulau Kei Besar dapat dilihat pada Gambar 7. 
Tabel 7 Penentuan daerah penangkapan ikan karang

\begin{tabular}{|c|c|c|c|c|c|c|c|c|c|c|c|}
\hline \multirow{3}{*}{ Lokasi } & \multicolumn{9}{|c|}{ Parameter Penentuan DPI } & \multirow{3}{*}{$\sum \mathrm{P}$} & \multirow{3}{*}{ DPI } \\
\hline & \multirow{2}{*}{1} & \multirow{2}{*}{2} & \multirow{2}{*}{3} & \multirow{2}{*}{4} & \multirow{2}{*}{5} & \multicolumn{2}{|c|}{6} & \multicolumn{2}{|c|}{7} & & \\
\hline & & & & & & Nilai & Ket. & Nilai & Ket & & \\
\hline Kilwait & $\mathrm{P}$ & $\mathrm{P}$ & $\mathrm{CP}$ & $\mathrm{P}$ & $\mathrm{P}$ & 9 & $\mathrm{CP}$ & $44 \%$ & $\mathrm{CP}$ & 4 & $\mathrm{CP}$ \\
\hline Weduar & $\mathrm{P}$ & $\mathrm{P}$ & $\mathrm{CP}$ & $\mathrm{P}$ & $\mathrm{P}$ & 10 & $\mathrm{CP}$ & $53 \%$ & $\mathrm{P}$ & 5 & $\mathrm{CP}$ \\
\hline Ohoirenan & $\mathrm{P}$ & $\mathrm{P}$ & $\mathrm{CP}$ & $\mathrm{P}$ & $\mathrm{P}$ & 10 & $\mathrm{CP}$ & $44 \%$ & $\mathrm{CP}$ & 4 & $\mathrm{CP}$ \\
\hline Ohoiwait & $\mathrm{P}$ & $\mathrm{P}$ & $\mathrm{CP}$ & $\mathrm{P}$ & $\mathrm{P}$ & 11 & $\mathrm{P}$ & $69 \%$ & $\mathrm{P}$ & 6 & $\mathrm{P}$ \\
\hline Ngufit Bawah & $\mathrm{P}$ & $\mathrm{P}$ & $\mathrm{CP}$ & $\mathrm{P}$ & $\mathrm{P}$ & 8 & $\mathrm{CP}$ & $43 \%$ & $\mathrm{CP}$ & 4 & $\mathrm{CP}$ \\
\hline Yamtel & $\mathrm{P}$ & $\mathrm{P}$ & $\mathrm{CP}$ & $\mathrm{P}$ & $\mathrm{P}$ & 9 & $\mathrm{CP}$ & $46 \%$ & $\mathrm{CP}$ & 4 & $\mathrm{CP}$ \\
\hline Fako & $\mathrm{P}$ & $\mathrm{P}$ & $\mathrm{CP}$ & $\mathrm{P}$ & $\mathrm{P}$ & 11 & $\mathrm{P}$ & $59 \%$ & $\mathrm{P}$ & 6 & $\mathrm{P}$ \\
\hline Hollat & $\mathrm{P}$ & $\mathrm{P}$ & $\mathrm{CP}$ & $\mathrm{P}$ & $\mathrm{P}$ & 8 & $\mathrm{CP}$ & $50 \%$ & $\mathrm{P}$ & 5 & CP \\
\hline Ohoifau & $\mathrm{P}$ & $\mathrm{P}$ & $\mathrm{CP}$ & $\mathrm{P}$ & $\mathrm{P}$ & 10 & $\mathrm{CP}$ & $60 \%$ & $\mathrm{P}$ & 5 & $\mathrm{CP}$ \\
\hline
\end{tabular}

Keterangan:

$\begin{array}{ll}\text { TP } & \text { : Tidak potensial } \\ \text { CP } & \text { : Cukup potensial } \\ \text { P } & \text { : Potensial }\end{array}$

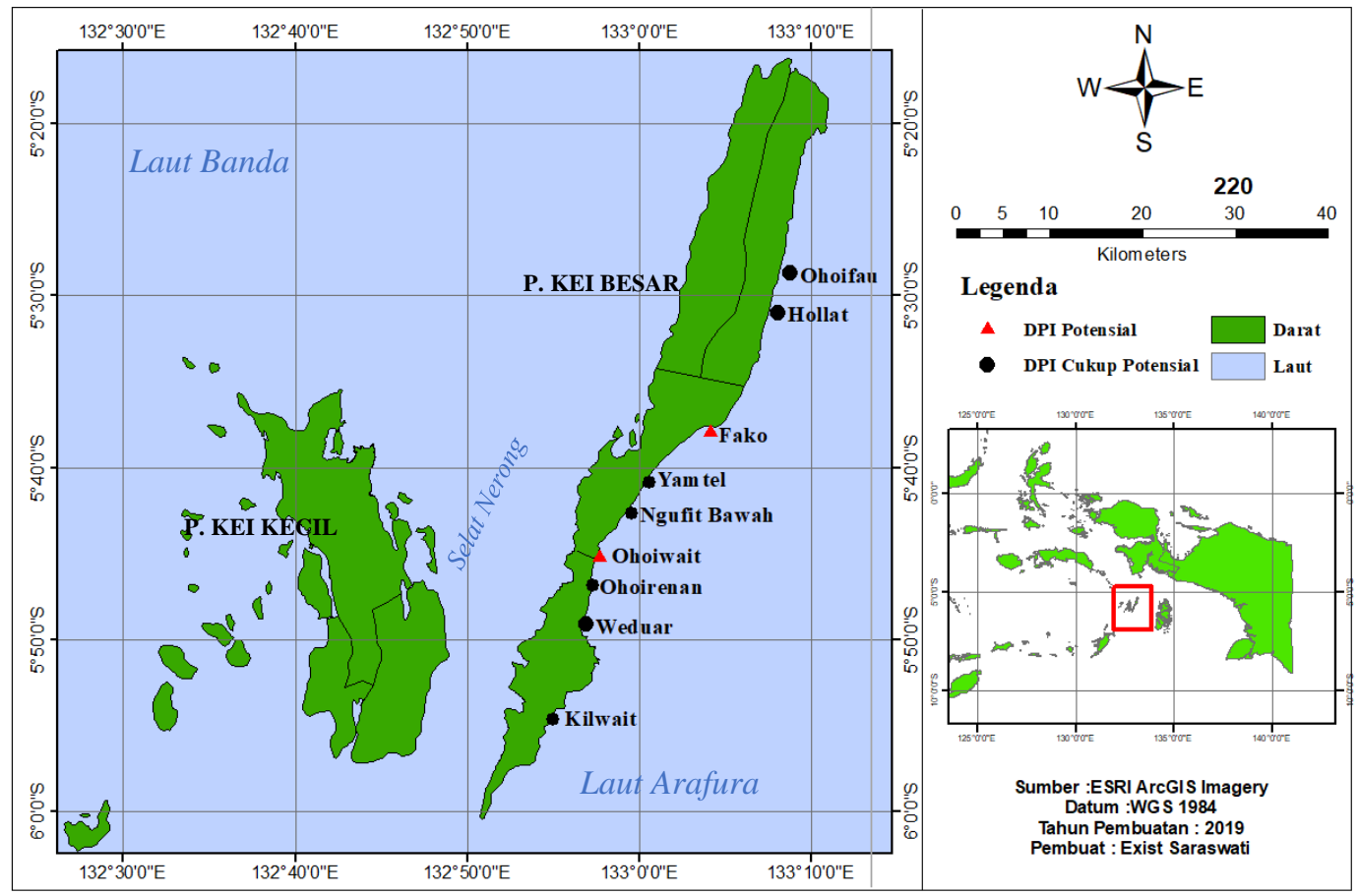

Gambar 7 Daerah penangkapan ikan karang di pesisir timur Pulau Kei Besar

Tiga jenis ikan paling potensial di lokasi Ohoiwait adalah ikan Epinephelus merra, Halichoeres hortulanus, dan Thalassoma Hardwicke serta lokasi Fako merupakan daerah penangkapan ikan paling potensial untuk ikan Pterocaesio pisang, Acanthurus lineatus, dan Lutjanus bohar.

Gambar 7 menunjukkan lokasi penangkapan ikan karang yang merupakan penilaian dari aspek biologi dan teknis. Lokasi penangkapan ikan yang tepat juga ditunjang oleh kualitas perairan atau kondisi perairan yang baik. Kondisi perairan yang baik dapat membantu pertumbuhan biota-biota laut yang ada, termasuk ikan karang tersebut. Kondisi perairan yang baik untuk ekosistem terumbu karang yang menjadi habitat ikan karang dipengaruhi oleh beberapa parameter yaitu padatan tersuspensi, suhu, salinitas, dan kecerahan (Nybakken 1988). 
Secara umum, kondisi wilayah perairan di Pulau Kei Besar sesuai untuk habitat ikan karang. Hal tersebut didukung oleh riset dari Dinas Kelautan dan Perikanan Kabupaten Maluku Tenggara tahun 2010 yang menyebutkan bahwa perairan Kei Besar memiliki kandungan padatan tersuspensi sebanyak $0.27 \mathrm{mg} / \mathrm{l}-0.55 \mathrm{mg} / \mathrm{l}$, suhu rata rata tahunan berkisar antara $28-30{ }^{\circ} \mathrm{C}$, dan salinitas sebesar $35 \%$. Kecerahan perairan juga dinilai sangat baik yaitu mencapai $20 \mathrm{~m}$. Nilai ini sesuai dengan kriteria yag ditetapkan oleh KepMen LH No 51 Tahun 2004 yang menyatakan bahwa kondisi perairan yang baik untuk biota laut di ekosistem terumbu karang adalah perairan yang mengandung padatan tersuspensi tidak lebih dari $20 \mathrm{mg} / \mathrm{l}$, suhu berkisar antara $28-32{ }^{\circ} \mathrm{C}$, salinitas sebesar $33-34 \%$, dan kecerahan lebih dari 5 meter. Peristiwa upwelling juga sering terjadi di perairan di pesisir timur Pulau Kei Besar, khususnya pada saat musim timur (DKP 2010). Hal ini sesuai dengan pernyataan Nontji (2007) dan diperkuat oleh penelitian Wijaya et al (2017) bahwa wilayah laut Indonesia terutama di sekitar laut Banda terjadi peristiwa upwelling setiap tahunnya. Penelitan lain juga menyebutkan bahwa perairan Kei Besar baik untuk kegiatan perikanan, didukung oleh kualitas perairan yang baik (Rugebregt 2014).

Kondisi perairan dengan kualitas yang baik dan didukung dengan sumberdaya ikan yang tersedia dapat menjadikan perairan pesisir timur Pulau Kei Besar sebagai daerah penangkapan ikan, namun kebiasaan nelayan setempat yang kurang tepat dapat merusak daerah penangkapan ikan tersebut. Berdasarkan pengamatan yang telah dilakukan, di beberapa lokasi penelitian ditemukan adanya jaring yang tersangkut di terumbu karang dan ditinggal begitu saja oleh nelayan. Ada pula ditemukannya indikasi bekas bom yang ditandai dengan rusaknya terumbu karang dalam radius yang kecil sekitar 5 meter, padahal area disekitarnya masih tergolong baik. Selain itu di beberapa lokasi juga ditemukan patahan-patahan terumbu karang yang membentuk suatu jalur. Hal ini dipredikisi merupakan bekas dari penggunaan alat tangkap pukat oleh nelayan. Berdasarkan hal tersebut, maka dapat dikatakan bahwa alat tangkap yang telah disebutkan diatas tidak baik untuk dioperasikan di daerah penangkapan ikan dengan habitat terumbu karang karena dapat merusak terumbu karang tersebut dan secara berkelanjutan akan mengurangi populasi ikan karang yang ada di dalamnya. Sesuai dengan pernyataan Mangi dan Roberts (2006) bahwa kerusakan ekosistem terumbu karang paling banyak disebabkan oleh alat penangkapan ikan, terutama alat tangkap yang aktif. Oleh karena itu, Sala et al (2017) menyatakan bahwa alat tangkap aktif tersebut semestinya dilarang beroperasi pada zona yang merupakan habitat dari terumbu karang.

Alat tangkap yang dianjurkan untuk dioperasikan di area terumbu karang adalah pancing, panah, dan bubu. Seperti penelitian yang dilakukan oleh Chiappone et al (2005), bahwa kerusakan ekosistem yang disebabkan akibat alat tangkap pancing yang lepas adalah sangat kecil sehingga cukup ramah untuk lingkungan. Selain itu, penelitian yang dilakukan oleh Latuconsina (2010) di Kawasan Konservasi Laut Pulau Pombo, Maluku dengan mengidentifikasi 8 alat tangkap yaitu pancing ulur, jaring insang permukaan, jaring insang dasar, jala, bubu, bameti, potas, dan bom molotov, menyatakan bahwa alat tangkap yang ramah lingkungan dan sesuai untuk area terumbu karang adalah pancing ulur, panah serta bubu.

\section{KESIMPULAN DAN SARAN}

Tercatat sebanyak 15338 individu ikan karang target yang termasuk ke dalam 14 famili, 58 genus, serta 176 spesies di pesisir timur Pulau Kei Besar dengan keanekaragaman ikan di seluruh lokasi pengamatan tergolong sedang, keseragaman ikan tergolong tinggi dan dominansi ikan yang rendah. Kelimpahan ikan karang tertinggi berada di lokasi Fako dengan persentase layak tangkap ikan yang berbeda-beda di setiap lokasi pengamatannya.

Perairan Kilwait, Weduar, Ohoirenan, Ngufit Bawah, Yamtel, Hollat, dan Ohoifau merupakan perairan yang cukup potensial untuk menangkap ikan karang. Ohoiwait adalah daerah penangkapan ikan Epinephelus merra, Halichoeres hortulanus, dan Thalassoma Hardwicke yang potensial. Fako 
merupakan daerah penangkapan ikan potensial untuk ikan Pterocaesio pisang, Acanthurus lineatus, dan Lutjanus bohar.

\section{DAFTAR PUSTAKA}

Allen GR, Adrim M. 2003. Review article; Coral reef fishes of Indonesia. Jurnal Zoologi. 42(1): 1-72.

Allen GR, Erdmann MV. 2012. Reef Fishes of the East Indies. Tropical Reef Research. Australia (AU): New World Publication.

Allen GR, Steene R, Humann P, De Loach N. 2003. Reef Fish Identification: Tropical Pacific. Australia (AU): New World Publication.

[BPS] Badan Pusat Statistik. 2017. Kecamatan Kei Besar dalam Angka. Maluku Tenggara (ID). BPS Kabupaten Maluku Tenggara.

[BPS] Badan Pusat Statistik. 2017. Kecamatan Kei Besar Selatan dalam Angka. Maluku Tenggara (ID). BPS Kabupaten Maluku Tenggara.

[BPS] Badan Pusat Statistik. 2017. Kecamatan Kei Besar Utara Timur dalam Angka. Maluku Tenggara (ID). BPS Kabupaten Maluku Tenggara.

Bukhari, Adi W, Kurniawan. 2014. Pendugaan Daerah Penangkapan Ikan Tenggiri berdasarkan Distribusi Suhu Permukaan Laut dan Klorofil-A di Perairan Bangka. Bangka Belitung (ID): Universitas Bangka Belitung.

[DKP] Dinas Kelautan dan Perikanan. 2010. Kajian Potensi Sumberdaya Kelautan dan Perikanan. Maluku Tenggara (ID). Kabupaten Maluku Tenggara.

[DKP] Dinas Kelautan dan Perikanan. 2016. Kajian Potensi Sumberdaya Kelautan dan Perikanan.. Maluku Tenggara (ID). Kabupaten Maluku Tenggara.

Direktorat Konservasi Kawasan dan Jenis Ikan. 2012. Pedoman Teknis Evaluasi Efektivitas Pengelolaan Kawasan Konservasi Perairan, Pesisir dan Pulau-Pulau Kecil (E-KKP3K). Jakarta (ID): Direktorat Konservasi Kawasan dan Jenis Ikan, Direktorat Jenderal Kelautan, Pesisir dan PulauPulau Kecil, Kementerian Kelautan dan Perikanan.

English S, Wilkinson C, Baker V. 1994. Survei Manual for Tropical Marine Resources. Asean-Australia Marine Science Project: Living Coastal Resources. Australia (AU): Australian Institute of Marine Science.

Froese R and Pauly D. 2014. Fishbase. World Wide Web electronic publication.

Green, A.L and Bellwood, D.R. 2009. Monitoring Coral Reef Resilience: Functional Groups of Herbivores. A Practical Guide For Coral Reef Managers in The Asia Pacific Region. Switzerland (CH): IUCN Working Group on Climate Change and Coral Reefs.

Hadi, Sutrisno. 2001. Metodologi Research Jilid III. Yogyakarta (ID): Andi Offset.

Kent M, and C Paddy. 1992. Vegetation Description and Analysis: a Practical Approach. London (GB): Belhaven Press.

Latuconsina H. 2010. Identifikasi alat penangkapan ikan ramah lingkungan di Kawasan Konservasi Laut Pulau Pombo Provinsi Maluku. Jurnal Ilmiah Agribisnis dan Perikanan. 3(2).

Mangi SC, Roberts CM. 2006. Quantifying the environmental impacts of artisanal fishing gear on Kenya's coral reef ecosystems. Marine Pollution Bulletin 52(12):1646-1660.

Mukhtar. 2010. Klasifikasi Alat Penangkapan Ikan. Dinas Kelautan dan Perikanan. 
Mujiyanto dan Hartati. 2011. Komposisi dan Kelimpahan Stok Ikan Karang serta Pertumbuhan Biota Penempel pada Terumbu Karang Buatan di Teluk Saleh, Nusa Tengara Barat. Prosiding Seminar Nasional Tahunan Viii Jilid II Manajemen Sumberdaya Perikanan. Yogyakarta (ID): Jurusan Perikanan UGM.

Nontji A. 2007. Laut Nusantara. Jakarta (ID): Djambatan.

Nybakken J.W. 1988. Biologi Laut (Suatu Pendekatan Ekologis). Jakarta (ID): Gramedia.

Odum EP. 1971. Fundamental of Ecology. Second Edition. WB Sounder Company Alumni Fondation Professor of Zoology. Georgia (DE): Georgia University.

Odum EP. 1996. Dasar-Dasar Ekologi. Samingan T, penerjemah. Yogyakarta(ID): Gadjah Mada University Press. Terjemahan dari: Fundamental of ecology.

Riduwan. 2004. Metode Riset.Jakarta (ID): Rineka Cipta.

Rugebregt MJ. 2014. Kualitas perairan Kei Besar Selatan, Kabupaten Maluku Tenggara. Jurnal neritic 5(2): 60-113.

Sala R, Simbolon D, Wisudo SH, Haluan J, Yusfiandayani R. 2017. Kesesuaian jenis alat tangkap ikan pada zona pemanfaatan tradisional Misool, Raja Ampat. Jurnal Marine Fisheries 9(1):25-40.

Simbolon D, Irnawati R, Sitanggang LP, Ernaningsih D, Tadjuddah M, Manoppo VEN. 2009. Pembentukan Daerah Penangkapan Ikan. Bogor (ID): Dept PSP IPB.

Simbolon, D. 2011. Bioekologi dan dinamika daerah penangkapan ikan. Bogor (ID): IPB Press.

Supriharyono. 2007. Pengelolaan Ekosistem Terumbu Karang. Jakarta (ID): Djambatan.

Triandiza, T. 2013. Diversitas Ikan pada Komunitas Padang Lamun di Pesisir Perairan Pulau Kei Besar, Maluku Tenggara. Seminar Nasional Sains dan Teknologi V. Lembaga Penelitian Universitas Lampung.

Wijaya AP, Putra II, Sukmono A. 2017. Analisis pola sebaran area upwelling menggunakan parameter suhu permukaan laut, klorofil-a, angin dan arus, secara temporal tahun 2003-2016 (Studi kasus: Laut Banda). Jurnal Geodesi Undip. 6(4):2337-845.

Wulandari U. 2017. Analisis Daerah Penangkapan Ikan dan Teknologi Penangkapan Ikan di Kecamatan Enggano, Bengkulu Utara. [Tesis]. Bogor (ID): Institut Pertanian Bogor.

WWF-Indonesia. 2016. Pengamatan Komunitas Bentik dan Ikan Karang di Kawasan Konservasi Perairan dan Pulau-Pulau Kecil Pulau Kei Kecil, Pulau-Pulau, dan Pulau Sekitarnya-Maluku Tenggara. Jakarta (ID): WWF Indonesia. 